Protestantismo em Revista é licenciada sob uma Licença Creative Commons.

http://dx.doi.org/10.22351/nepp.v45i1.3667

\title{
INTERFACES ENTRE DIREITO E RELIGIÃO: A INFLUÊNCIA DA HEGEMONIA CATÓLICA APOSTÓLICA ROMANA NA CONSTRUÇÃO DA REALIDADE JURÍDICA OCIDENTAL
}

\author{
Interfaces between law and religion: the influence of Catholic Apostolic Roman hegemony \\ in the construction of western legal reality
}

\author{
Noli Bernardo Hahn* \\ Alana Taíse Castro Sartori*
}

\begin{abstract}
Resumo:
Neste artigo, analisa-se a influência da religião sobre a formação da realidade jurídica ocidental, com ênfase na estrutura de linguagem hegemônica que perpassa os ensinamentos religiosos e reflete nas legislações intercorrentes. Tendo em vista que o Direito e a Religião são essencialmente estruturas de linguagem, questiona-se se os interesses hegemônicos percebidos em determinados contextos históricos possuem vinculação com a linguagem religiosa e se esta influência se estende à ciência jurídica. Uma das conclusões é a de que a estrutura de linguagem metafísica, oriunda da Filosofia grega, foi determinante para a influência da religião cristã sobre a formação da realidade jurídica ocidental.
\end{abstract}

Palavras-chave: Direito. Religião. Hegemonia. Estrutura de linguagem. Metafísica.

\begin{abstract}
:
In this article, it is analyzed the influence of religion on the formation of Western legal reality, with emphasis on the hegemonic language structure that permeates the religious teachings and reflects in the intercurrent legislations. Given that Law and Religion essentially are structures of language, it is questioned whether hegemonic interests, perceived in certain historical contexts, are linked to religious language and whether this influence extends to legal science. One of the conclusions is that the structure of metaphysical language, originating from the Greek Philosophy, was determinant for the influence of the Christian religion on the formation of Western legal reality.
\end{abstract}

Keywords: Law. Religion. Hegemony. Language structure. Metaphysics.

[Texto recebido em maio de 2019 e aceito em novembro de 2019, com base na avaliação cega por pares realizada por pareceristas ad hoc]

* Doutor. URI, Campus de Santo Ângelo. E-mail: nolihahn@santoangelo.uri.br

* Graduada em Direito da URI, campus Santo Ângelo. Bolsista de iniciação científica, modalidades PIIC e PROBIC/URI. E-mail: alana_t.c._sartori_@hotmail.com 


\section{Introdução}

Religião e Direito relacionam-se enquanto estruturas de linguagem que buscam a ordenação do convívio em sociedade. Independentemente do fundamento utilizado para a legitimação da imposição normativa, seja este fundamento racional ou religioso, tem-se caracterizado níveis de dominância da vontade de grupos de poder em relação à vontade soberana do povo. Não é viável para o bem estar social cogitar uma forma de organização pautada na ausência de um poder de mando, da mesma forma que se este for utilizado de maneira excessiva, constrói-se um sistema totalitário e nocivo para a população. É necessária a existência equilibrada entre poder normativo e liberdade individual para a constituição de uma sociedade justa e harmônica.

Entretanto, no decorrer dos períodos históricos, é notável que o poder estatal se sobressaia às liberdades individuais. $\mathrm{O}$ abuso do poder normativo criou situações insustentáveis pela opressão da população, na medida em que os regramentos passaram a assegurar interesses voltados ao imperialismo e à dominação dos governantes. Não é possível desconsiderar a contribuição das correntes religiosas para a consolidação das sociedades holistas ${ }^{1}$, pois a estrutura de pensamento metafísico que propagaram ao longo dos tempos legitima a imposição de sistemas autoritários. Neste sentido, objetiva-se demonstrar como o Cristianismo ajudou a moldar uma doutrina de dominação, legitimando as ordens jurídicas hegemônicas. Em outras palavras, tendo em vista que o Direito e a Religião são essencialmente estruturas de linguagem, questiona-se se os interesses hegemônicos percebidos em determinados contextos históricos possuem vinculação com a linguagem religiosa e se esta influência se estende à ciência jurídica.

Destarte, a seguir, num primeiro momento, realiza-se uma análise e uma descrição histórica da propagação do ideal de hegemonia que emerge a partir do imperialismo romano e da dogmática da igreja cristã, ideal que incide no direito medieval. Em um segundo momento, numa ótica predominantemente interpretativa, evidencia-se a manutenção das teses hegemônicas metafísicas durante a idade moderna e alguns de seus reflexos negativos na contemporaneidade.

1 Neste artigo, a ideia de sociedades holistas, teoricamente, relaciona-se à concepção metafísica de universalidade. Nesta ótica, compreende-se a relação de holismo com sistemas autoritários: a linguagem holística, universal, metafísica, impede a inclusão de singularidades, particularidades e de especificidades. Sob esta ótica, a totalidade contrapõe-se a infinito, trazendo-se presente categorias de Emmanuel Levinas. A sociedade holística, enquanto posta em base metafísica, encerra-se em totalidade. (LEVINAS, Emmanuel. Totalidade e Infinito. Lisboa: Edições 70, 1980). 


\section{Ideal Hegemônico a Partir do Imperialismo Romano e da Dogmática Apostólica Romana aplicada no Direito Medieval}

Pode-se conceber que, ao remontar em sua historicidade, o Direito firmou-se a partir de um discurso metafísico que, difundido também através das religiões, atua como fonte dos discursos hegemônicos. Hegemonia, neste sentido, é tratada como processo de padronização do mundo a um único modelo político, econômico, social e cultural estipulado como ideal, refletindo na polarização entre aqueles que dominam e aqueles que sofrem a dominação. Na seara das legislações perpassa um processo de regulamentação, valorização e desvalorização de condutas e de convicções que se enquadram ou não no processo de universalidade. ${ }^{2}$ Atenta-se para o fato de que a metafísica, na perspectiva de Vattimo ${ }^{3}$, está por detrás de todo pensamento arbitrário e universalista que atua como embasamento para a consolidação e legitimação das correntes religiosas, inclusive do Cristianismo. A hegemonia, portanto, adquire status metafísico por possuir um ideal de dominação e universalização cultural, política e ideológica. Tal vislumbra-se, com maior evidência, no ocidente, a partir da fundação do Império Romano.

Roma possuía uma política imperialista que almejava expandir seu império às nações, explicando-se, assim, as inúmeras guerras travadas na conquista de territórios. Neste processo, os povos dominados eram coagidos a seguirem as leis e a cultura romanas, representando um processo de padronização cultural universal. ${ }^{4}$ A sociedade romana formou-se, desta forma, por quatro classes distintas: os patrícios, descendentes das primeiras famílias que povoaram Roma; os plebeus, representando os comerciantes, artesãos e a parcela trabalhadora da população; os clientes, classe formada pelos estrangeiros pobres que se submetiam à dependência dos patrícios; e os escravos, presos de guerra, que não possuíam direitos e cujo trabalho braçal era obrigatório. No que se refere à Religião do império, inicialmente era politeísta, baseada em uma apropriação da imagem dos deuses gregos, bem como extremamente individualista, chegando a considerar a população de classes baixas apenas objetos. ${ }^{5}$ Importante frisar que remanescentes do povo judeu $^{6}$ compunham a sociedade romana, dentre os quais se sobressaiu a figura de Jesus Cristo, considerado um messias para grande parte do ocidente, proclamando ensinamentos baseados na caridade, na não-violência e no amor ao próximo. ${ }^{7}$

2 SANTOS, Boaventura de Sousa. Se Deus fosse um ativista dos direitos humanos. São Paulo: Cortez, 2014.

3 VATTIMO, Gianni. Adeus à verdade. Petrópolis: Vozes, 2016. Destaca-se, para esta discussão temática, o primeiro capítulo do livro ora referido.

4 SANTOS, Rogério Dultra dos. A Institucionalização da Dogmática Jurídico-Canônica Medieval. In: WOLKMER, Antonio Carlos [org.]. Fundamentos de História do Direito. Belo Horizonte: Del Rey, 2014, p. 261281.

5 SCALQUETTE, Rodrigo Arnoni. História do Direito: perspectivas histórico-constitucionais da relação entre Estado e Religião. São Paulo: Atlas, 2013.

6 A diferença constante nos vocábulos "semita", "israelita" e "judeu" é apenas formalística, pois são três maneiras distintas de se referir ao mesmo povo.

7 VATTIMO, Gianni. Acreditar em Acreditar. Lisboa: Relógio D'Água Editores, 1998. 
Os adeptos das ideias de Jesus Cristo formaram uma comunidade numerosa, representando um risco para o governo de Roma, uma vez que se formava uma estrutura de poder paralela ao do imperador. Destarte, após a condenação de Cristo à morte na cruz e o comprometimento do apóstolo Pedro em construir uma igreja para os seus seguidores, em torno do ano 67 d. C., o imperador romano Nero institucionalizou a perseguição aos cristãos. A partir deste período, o Cristianismo propagado pelo discípulo Pedro e outros seguidores, como Paulo, adquire características institucionalizadas e é reconhecido historicamente como Religião. ${ }^{8}$ Apenas em meados de 306 d.C., o imperador Constantino consolidou o Cristianismo como Religião oficial do Império Romano, no interesse de utilizar a doutrina cristã também como meio de aumentar o poder de domínio sobre outros povos. ${ }^{9}$ Para os estudiosos, neste momento da história romana, constata-se, de forma mais intensa, a aliança entre Igreja e Estado, bem como a grande concentração de poder em suas instituições. Para Vattimo e De Caputo, a revolução iniciada por Constantino foi necessária para manter o controle social, mas, ao mesmo tempo, foi “Un pacto con el diablo que otorgó a los líderes de la Iglesia la autoridad necesaria no sólo para definir la ortodoxia, sino también para imponer su visión acerca de la propia uniformidad y homogeneidad de la Iglesia."10

A partir do reconhecimento do cristianismo como Religião oficial, o Império Romano possuía mais um aliado para seu ideal de colonização e expansão de sua política. A Igreja Cristã, neste aspecto, contribuiu para amplificar o alcance de seus ensinamentos. Utilizando-se da perspectiva de que a Igreja era a morada divina na terra, sua sistemática era legítima e verdadeira. Impunha-se que a sociedade e o Estado deveriam adequar-se a sua imagem, que representava a imagem de Deus na Terra. ${ }^{11}$ Assim, a Igreja instituiu dogmas e empreendeu um trabalho de colonização do mundo ocidental, submetendo os mais diversos povos a seus ensinamentos por meio da força e da coerção institucionalizada. Por outro lado, a própria Igreja, ao se tornar uma instituição tão poderosa quanto a figura do imperador e do Estado, acabou por atuar como um facilitador à queda do Império Romano e à instituição do regime feudal em meados do século X. Santos ${ }^{12}$ leciona que o clero tornava-se uma classe influente e que muitas de suas pregações incentivavam movimentos sociais advindos da classe plebeia, uma vez que se encontrava descontente com a opressão estatal e com a falta de trabalho resultante do sistema escravagista.

Por volta de 395 d.C, a então capital romana Constantinopla, após se tornar uma potência do mundo antigo, é desmembrada e passa a fazer parte do Império Bizantino. Neste processo de fragmentação do domínio Romano, a Igreja Cristã ainda permaneceu unificada sob o comando de um único papa, apesar de iniciarem fortes tensões entre as

SCALQUETTE, 2013.

SANTOS in WOLKMER, 2014.

10 VATTIMO, Gianni; DE CAPUTO, John. Después de la muerte de Dios: conversaciones sobre religión, política y cultura. Barcelona: Paidós, 2010, p. 20.

11 VATTIMO; DE CAPUTO, 2010.

12 SANTOS in WOLKMER, 2014. 
Igrejas fundadas em Roma (então capital do Império Romano) e em Constantinopla, principiadas pela adoção de práticas ecumênicas distintas em ambas as capitais. ${ }^{13}$ Ainda, importa ressaltar o papel político desempenhado pelos missionários romanos e bizantinos. De acordo com Knowles e Obolensky, "o missionário bizantino aparece em seu duplo papel de homem apostólico, enviado para estender as fronteiras espirituais do Reino de Deus, e de embaixador do imperialismo romano oriental" 14 .

Enquanto o Império Bizantino, na parte oriental da Europa, permaneceu dominante até meados de 1453, o Império Romano do ocidente sofreu a invasão dos povos habitantes da Germânia, que por volta de 476 d.C destituíram o maior reino da antiguidade. Importante ressaltar que deste processo de invasão e colisão cultural surgiu uma das concepções que mais influenciaria a hegemonia ocidental pautada pela desigualdade: o etnocentrismo, fundado na auto identificação cultural superior de um povo. Neste sentido, os Romanos entendiam-se como "raça diferenciada", relacionando-se em nível superior de hierarquia perante as demais. Tal entendimento manteve a organização estatal Romana em seus últimos anos, pois promovia a unidade do povo sob o sentimento de pertencimento à nação ao mesmo tempo em que legalizava a discriminação étnica perante os germânicos. Entretanto, mesmo com as tentativas de manter a unidade estatal, o Império Romano foi desmantelado. A queda da capital de Roma tem importância fundamental para a história, pois representa marco entre a passagem da Idade Antiga para a Idade Média e o regime feudal na Europa ocidental. Apesar de toda a mudança política de descentralização de poder que instituiu o novo regime, a Igreja subsistiu como foco central de influência e dominação por meio de sua arbitrariedade divinizada. ${ }^{15}$

Em 1054, por fim, tem-se a fundação do Catolicismo Apostólico Romano, após o "Cisma do Oriente", isto é, a ruptura entre as Igrejas Cristãs de Roma e Constantinopla. Segundo Knowles e Obolensky ${ }^{16}$, as sedes Cristãs situadas em ambas as capitais possuíam a convicção de que seus respectivos impérios eram universais, bem como reconheciam apenas a si mesmas como legitimadas a transmitir os ensinamentos cristãos. A polarização entre as duas teses hegemônicas fulminou na divisão da Igreja Cristã em Ortodoxa Grega, pertencente ao Império Bizantino, e Apostólica Romana, dominando a porção ocidental da Europa. A partir do desmantelamento do Império Romano, um novo regime de governo se estabelece entre os povos que estavam sob seu domínio. Trata-se do surgimento do Feudalismo na Europa Ocidental (séculos IX a X), caracterizado pela formação de ilhas de governo autônomas e descentralizadas, sendo que as famílias detentoras de propriedades possuíam autoridade sobre aqueles que trabalhavam em suas terras, formando uma relação de submissão entre servos e senhores. Para o campo de estudo da história, a instituição do regime feudal identifica a Idade Média, compreendida entre os séculos $\mathrm{V}$ a XV. Interessante frisar que o império ainda subsistiu como Sacro Império Romano-germânico, porém sem o

\footnotetext{
KNOWLES, David; OBOLENSKY, Dimitri. Nova História da Igreja II: A Idade Média. Petrópolis: Vozes, 1973.

KNOWLES; OBOLENSKY, 1973, p. 24.

SANTOS in WOLKMER, 2014.

KNOWLES; OBOLENSKY, 1973, p. 30.
} 
mesmo poder da antiguidade. ${ }^{17 E ́}$ neste período que a Igreja Católica centraliza seu poder e serve de modelo para a construção da estrutura organizacional dos Estados Modernos (século XV) e da formalização do Direito enquanto ciência jurídica autônoma.

O professor José de Lima Lopes explica que, no início da Idade Média, a Igreja era uma instituição descentralizada, sendo "uma comunidade sacramental, espiritual, não jurídica e muito mais uma federação de Igrejas nacionais do que uma rígida monarquia centralizada em Roma." ${ }^{18}$ De acordo com o autor, mesmo após o Cisma do Oriente, o contexto social impedia o exercício hegemônico de apenas um centro de poder, sendo este exercido pelos eventuais Monarcas e pelas relações entre os senhores feudais e seus servos. A autoridade episcopal era tradicional e com pouca eficácia na seara da política até meados de 1073, quando o papa Gregório VII revolucionou a organização eclesiástica. A reforma gregoriana objetivava a emergência da Igreja enquanto autoridade suprema. No período de 1073 e 1085, uma série de decretos eclesiásticos promoveu a unificação do poder da Igreja Católica Apostólica Romana, organizando-a enquanto instituição burocrática e hierárquica, cuja chefia absoluta pertencia ao papa ${ }^{19}$. Os compilados normativos oriundos do clero, neste período, formaram o Corpus Iuris Canonici, também denominado Direito Canônico ou Lei do Cânon. Interessante frisar que um dos principais aspectos deste sistema jurídico consistia na afirmação de que o papa era a autoridade única competente para legislar e interpretar as normas, sendo que as discussões legislativas eram protagonizadas pelos concílios com embasamento nas escrituras bíblicas. Da mesma forma, a noção de justiça se baseava na ideia distributiva ${ }^{20}$, o que possibilitava a unificação dos poderes administrativo, legislativo e judiciário. ${ }^{21}$

O Direito Canônico foi fundamental para a construção da realidade ocidental e contemporânea, tanto em matéria cultural, quanto em matéria jurídica. As primeiras normatizações acerca de regras de competência e de jurisdição, a formalização e a racionalização do processo, a formação de tribunais e o próprio processo de inquirição surgiram a partir da Igreja Católica, pois o ensino jurídico e a formação do profissional do Direto, na época, ocorriam junto ao poder eclesiástico, resgatando bases conceituais da filosofia grega. No que se refere às regras de jurisdição e competência, o processo canônico distinguia-se por ser um procedimento conduzido por profissionais do Direito, por reconhecer uma estrutura de recursos que uniformizada, concentrava e centralizava o

17 SANTOS in WOLKMER, 2014.

18 LOPES, José Reinaldo de Lima. O Direito na História: lições introdutórias. São Paulo: Max Limonad, 2002, p. 84.

19 Gregório VII foi o responsável por dirigir em 1075 o Dictatus Papae, um documento que declarava o poder de legislar, julgar e depor reis, legítimo unicamente ao papa da Igreja Católica. Após o documento ser enviado ao imperador Henrique IV, causou uma série de tensões entre o poder secular e o poder religioso, originando a Guerra das Investiduras entre os séculos X e XII. (LOPES, 2002, p. 86).

20 Para Aristóteles, a justiça poderia ser dividida em distributiva e corretiva. A justiça distributiva baseia-se na ideia de proporção, ou seja, dar a cada um o que lhe é devido, de maneira igual. Por outro lado, a justiça corretiva é o intermediário entre a perda e o ganho, normalmente decidida em âmbito judicial, frente a um litígio. (ARISTÓTELES, 1991, p. 100-103)

21 LOPES, 2002.

Protestantismo em Revista | São Leopoldo | v. 45, n. 01 | p. 27-44| jan./jun. 2019

Disponível em: <http:// periodicos.est.edu.br/index.php/nepp> 
poder, bem como, principalmente, pelo caráter predominantemente escrito do processo e pelas investigações partirem de uma perspectiva inquisitorial, ou seja, em benefício da acusação. Neste sentido, a Igreja foi responsável por dividir os foros de julgamento de acordo com a matéria das controvérsias, sendo um de acordo com a razão das pessoas (ex ratione personarum) e outro com a razão de matéria (ex ratione materiae). Também se originou um sistema de divisão de competência de julgamento, sendo que os membros do clero poderiam aplicar sanções de ordem sacramental, como a excomunhão aos fiéis pecadores, configurando o "foro da consciência", ou aplicar sanções de ordem jurídica em caso de infração à lei canônica, o "foro do juiz". ${ }^{22}$

Por outro lado, a formalização e racionalização do processo, preconizadas pela Igreja Católica, se caracterizavam pela organização do processo e da audiência, consistindo em, primeiramente, a apresentação da demanda pela parte autora ao juízo competente e, posteriormente, a convocação do réu ao foro para tomar ciência da queixa. Havia, ainda, a figura dos notários, cuja atividade consistia em atuar como redator oficial dos juízos. E, apesar do sistema inquisitorial vigente, a partir do século XII, o processo canônico iniciou o progressivo abandono das chamadas provas irracionais, entendidas como aquelas produzidas pelo juízo de Deus, com viés mágico e supersticioso, estipulando-se, portanto, que os juízes deveriam proferir as sentenças com base nas informações fáticas que possuíam. ${ }^{23}$ Da mesma forma, não é possível desconsiderar as influências do Direito Canônico nas questões de matéria das legislações contemporâneas. Destacam-se, portanto, a construção normativa principalmente na seara do direito civil, como o casamento monogâmico, o direito à sucessão e o princípio contratual do pacta sunt servanda. ${ }^{24}$

Todavia, afastando-se do caráter dogmático do Direito Canônico e investigando os fundamentos de sua construção, percebe-se que os cânones foram as primeiras manifestações de Direito positivado a partir da estrutura metafísica do discurso religioso, pois fundava-se na imposição de uma "verdade a partir de um lugar de saber inquestionável, nascido de uma prática social politicamente determinada." 25 Logo, o Direito, em certa medida, não derivava de uma realidade social, mas sim de uma interpretação de dogmas religiosos coagindo a sociedade a se adaptar aos seus ditames. A partir dos choques culturais advindos do projeto expansionista outrora protagonizado por Roma, as diferenças étnicas ficaram em evidência, sendo que, para fins de dominação, iniciam tendências etnocêntricas de hegemonia, instituindo o povo romano como o ideal. Consequentemente, fixaram-se políticas de violência, submissão e homogeneização da população através do pensamento teológico e político de bases metafísicas. ${ }^{26}$

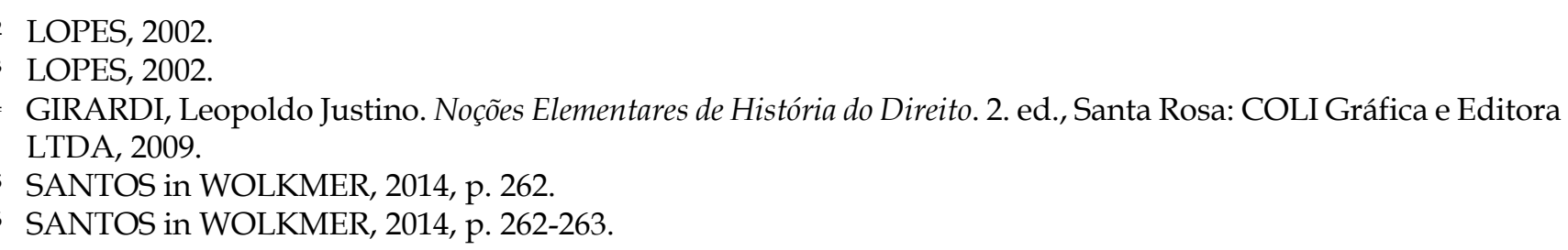


Nesta perspectiva, atenta-se para algumas teorias jurídicas e filosóficas surgidas no período medieval. Dentre os principais pensadores da época encontram-se Santo Agostinho, Tomás de Aquino, Guilherme de Ockham e Marsílio de Pádua. Para fins do presente estudo, recorre-se brevemente a uma explicação da teorização de Aquino, devido sua grande influência. Seus ensinamentos instituíram a metafísica tomista, baseando-se nas ideias filosóficas de Aristóteles. Tomás de Aquino considerava Deus uma entidade dotada de racionalidade e benevolência, facultando aos seres humanos o uso de sua razão para organizar sua vida em sociedade. Entretanto, a razão deve ser exercida nos limites da fé. Desta forma, o pensamento tomista fundou concepções totalitárias e universalistas, pois admitia ser Deus o único detentor da racionalidade plena e que os seres humanos poderiam exercitar sua razão apenas dentro das regras naturalizadas de fundamento transcendental. ${ }^{27}$

Assim sendo, compreende-se que, na Idade Média, o Direito derivava do Catolicismo Apostólico Romano e, através do fundamento metafísico, legitimava a perseguição aos indivíduos que não se encaixavam nas universalidades propostas. Tratouse do marco histórico que fundava o início do discurso discriminatório perpetuado pelas legislações intercorrentes. De acordo com Santos ${ }^{28}$, através da canonização das interpretações bíblicas de forma excludente, o Direito fixa pilares para sua estruturação baseadas em uma verdade pré-existente e superior à vontade humana, ou seja, imutável e autoritária. Apesar de a ciência jurídica adquirir gradual autonomia como verdade codificada, esta se volta para os interesses dos grupos sociais privilegiados, pois deles dependem as interpretações que serão bases das legislações. Desta forma, o Direito atua como mecanismo de opressão, pois se volta a punir a maioria da população, composta por servos, pobres, povos dominados e insatisfeitos com as condições de vida propostas pelos regimes arbitrários. Considera-se o movimento Inquisitorial, iniciado em 1233 pelo papa Gregório IX, como o ápice da institucionalização da opressão e da violência através das leis, ocorrido entre os séculos XV e XVII. Estima-se que, apenas no território correspondente à Alemanha atual, mais de 25 mil pessoas foram executadas pela acusação de heresia ou bruxaria. ${ }^{29}$ A justificativa do movimento encontra-se na política de expansão universalista da Igreja Católica, em busca de mais riquezas. Este movimento subjugou qualquer etnia ou minoria social que se mostrasse diferente e significou uma ameaça em potencial à subserviência da população. ${ }^{30}$

HOMMERDING, Adalberto Narciso. As doutrinas jurídicas cristãs da Idade Média: do voluntarismo agostiniano ao nominalismo de Guilherme de Ockham. De Ockham a teoria jurídica contemporânea. In: ROCHA, Leonel Severo; OLIVEIRA JUNIOR, José Alcebíades de. Diálogo e Entendimento: direito e multiculturalismo e políticas de cidadania e resolução de conflitos. CAPINAS: Millenium, 2018. Tomo 9, p. 191-216.

28 SANTOS In WOLKMER, 2014.

29 BBCBRASIL. Estudo do Vaticano diz que Inquisição torturou e matou menos do que se pensava. 2004. Disponível em:<https://www.bbc.com/portuguese/noticias/story/2004/06/040616_vaticanoms.shtml> Acesso em 06 Abr. 2019.

30 NASPOLINI, Samyra Haydeê. Aspectos Históricos, Políticos e legais da Inquisição. In: WOLKMER, Antonio Carlos [org.]. Fundamentos de História do Direito. Belo Horizonte: Del Rey, 2014, p. 282- 298. 
Destarte, percebe-se que, em âmbito ocidental, a instituição Católica Apostólica Romana foi responsável pela proliferação de discursos violentos baseados em ideais hegemônicos de supressão, principalmente, das diversidades culturais. Da mesma forma, atuou como pioneira na organização do Direito positivo e do sistema jurídico, organizando a estrutura normativa baseada na opressão e na exclusão, causando sérios problemas em âmbito nacional e internacional que se perpetuaram durante os séculos subsequentes ao início da Inquisição. Apesar da posterior formação dos Estados Soberanos e do processo de enfraquecimento do poder jurídico da Igreja, as consequências de seu discurso pautado na arbitrariedade metafísica são perceptíveis ainda na Idade Contemporânea. Assim sendo, em continuidade desta reflexão, argumenta-se como a estrutura linguística metafísica, difundida pelo Catolicismo, influenciou a concepção de Estados, da Ciência Jurídica autônoma e da própria corrente de pensamento que contrapunha à teológica: o racionalismo.

\section{Direito, Religião e Linguagem Hegemônica: incidências nas estruturas de poder ao longo da história}

Entende Boaventura de Sousa Santos ${ }^{31}$ que, o que é hegemônico, só pode ser determinado em seu contexto. Dentre os campos observáveis que possam demonstrar a hegemonia estão as relações econômicas, sociais, culturais e políticas baseadas na desigualdade e na dominação. Também, distingue-se que o fundamento encontrado para legitimar tais relações encontra-se na arbitrariedade metafísica, ou seja, na aceitação de conceitos dados como verdadeiros, imutáveis e naturalizados. Platão já mencionava em seus escritos que os humanos eram naturalmente desiguais, sendo a cada um reservado determinado papel na sociedade. Os governantes possuíam bênção ${ }^{32}$ divina, assim como acreditavam que as classes mais baixas eram criadas de acordo com a vontade dos deuses para servirem aos demais. Edmund Burke, mesmo no século XVIII, continuou pregando as ideias platônicas, pois acreditava que a reivindicação de autonomia das "classes servis" 33 era um atentando contra a própria natureza. ${ }^{34}$ Da mesma forma, Nietzsche em um diálogo sobre o que é bom e ruim, estipula que bom é tudo aquilo que traz poder ao ser humano, no sentido de que sua vontade possa subjugar a de outrem, complementando, ainda, que a felicidade nada mais é do que a sensação do poder crescente. E afirma: “Os fracos e malogrados devem sucumbir: primeira tese do nosso amor à humanidade. E ainda devem ser ajudados nisso." 35 Portanto, entende-se que hegemonia se refere a uma forma de

SANTOS, 2014.

32 Conforme explica Scalquette, os gregos não acreditavam que os governantes eram representantes deuses na sociedade, mas que se tratavam de homens que foram naturalmente abençoados pelos deuses. (2013, p. 17).

33 A terminologia "classes servis" é utilizada no sentido de se referir às classes sociais sem representatividade política, sendo composta, principalmente, pelos trabalhadores. (BEDIN, 2002, p. 26).

34 BEDIN, Gilmar Antônio. Os direitos do homem e o neoliberalismo. Ijuí: Ed. Unijuí, 2002.

35 NIETZSCHE, Friedrich. O Anticristo. Tradução de Renato Zwick. Porto Alegre: L \& PM, 2008.

Protestantismo em Revista | São Leopoldo | v. 45, n. 02 | p. 27-44| jan./jun. 2019

Disponível em: <http://periodicos.est.edu.br/index.php/nepp> 
compreender o mundo baseada na desigualdade e na dominação legitimadas pelo pensamento metafísico.

Os estudiosos que investigaram com maior atenção a construção da Lei do Cânon, preconizada pelo papa Gregório VII, afirmam que se tratou de um acontecimento revolucionário, pois o clero instituiu mudanças institucionais rápidas e conscientes. Entretanto, não deixou de ser um processo violento, principalmente pela reunião de cavaleiros sob o comando do papado que atuavam como uma espécie de milícia armada contra os imperadores, príncipes e senhores feudais. Anterior à revolução gregoriana, o mundo ocidental era reconhecido como pluralista, e as formas de governo, apesar de não democráticas, eram relativamente abertas aos cidadãos, resquícios ainda da organização social grega. Após a concentração de poder na instituição eclesiástica, formou-se um sistema de dominação burocrático e hierárquico, racional, legal e formalístico, que se voltava à garantia de interesses das classes privilegiadas, enquanto que subjugava grande parcela da população à miséria e à submissão. Neste sentido, é possível analisar que a estruturação dos Estados-nação foi realizada em semelhança à instituição eclesiástica ApostólicoRomana, marcando a transição para a Idade Moderna. ${ }^{36}$

Segundo Anderson ${ }^{37}$, a crise econômica que assolou o sistema feudal em meados dos séculos XIV e XV, conjuntamente com a ascensão da burguesia comercial, classe que se firmava de forma paralela e autônoma ao poder dos senhores feudais, foi um dos principais acontecimentos motivadores para o surgimento do primeiro modelo de nação soberana: o Estado Absolutista. De acordo com o autor, este modelo de Estado, inicialmente, atuava como mediador dos conflitos entre a nobreza e a burguesia, enquanto os primeiros indícios de um novo sistema de produção, que mais tarde seria reconhecido como capitalismo ${ }^{38}$, gradualmente se incorporavam às relações sociais da época. Portanto, é possível analisar que a transição do feudalismo para a sistemática dos Estados Soberanos não se deu de forma imediata, sendo que ambos os sistemas de governo coexistiram por um espaço de tempo. Consoante à firmação dos Estados Nacionais Absolutistas e o sistema de produção capitalista, o desenvolvimento das Grandes Navegações e a chegada dos europeus ao continente Americano, a Igreja Católica perde cada vez mais seu protagonismo e hegemonia, apesar de ainda exercer importante influência no governo e nas leis, atuando como legitimadora do poder monárquico. Para Marx e Engels, a nova organização formada pelos Estados Absolutistas "afogou os favores sagrados do êxtase religioso, do entusiasmo

Ressalta-se que, no presente estudo, se compreende que os escritos de Nietzsche possuíam uma linguagem irônica, revelando que o autor faz uma crítica mordaz a ideia de dominação do mais forte sobre o mais fraco.

36 LOPES, 2002.

37 ANDERSON, Perry. El estado absolutista. Madrid: Siglo XXI, 2007.

38 Para Marx, o capitalismo trata-se de um sistema de produção baseado nas trocas comerciais e na produção do capital, este último a ser acumulado pelos detentores dos meios de produção. Tal sistema de produção polariza a sociedade entre os Burgueses e os Proletários, ou seja, quem oferece os meios de serviço e obtém lucro sobre quem oferece a mão-de-obra para executar o serviço, mediante um salário. (MARX, 2017, p. 20-38). 
cavalheiresco, do sentimentalismo pequeno-burguês nas águas geladas do cálculo egoísta." 39.

O Estado Absolutista, ao ter seu sistema burocrático e hierárquico construído com base no sistema da Igreja, revelou-se uma organização violenta e autoritária para com as classes pobres. De acordo com o historiador Wellington José Campos ${ }^{40}$, esta forma de Estado se caracterizava pela centralização arbitrária dos poderes governamentais, sendo as ações do soberano limitadas apenas pelos direitos da aristocracia. O descontentamento com esta realidade de exclusão e submissão originou inúmeras revoltas, dentre as quais se destaca a Revolução Francesa, que em 1789 marcou o fim do absolutismo na França e, posteriormente, no mundo ocidental. Interessante frisar que neste período, dos séculos XVII ao século XVIII, surgem diversos pensadores europeus preocupados em teorizar acerca do papel do Estado, da política, do governo e da Religião, inaugurando uma nova corrente de pensamento Iluminista em substituição à ciência religiosa da Idade Média. Dentre estes pensadores, destacam-se nomes como Rousseau, Voltaire, Hobbes e Locke.

O Iluminismo (século XVIII) foi crucial para a construção da história contemporânea ocidental e marcou o fim da hegemonia Absolutista e Apostólico-Romana na Europa, deixando margem para o surgimento dos Estados Modernos, com destaque para o modelo Democrático de Direito ${ }^{41}$. Para o pensador Edgar Morin ${ }^{42}$, a Renascença ${ }^{43}$ inaugurada pelo movimento possibilitou o ressurgimento da filosofia de forma autônoma à Religião, estabelecendo a razão ${ }^{44}$ como instrumento de pesquisa, admitindo a produção de conhecimento através não mais da interpretação teológica, mas sim da experimentação empírico-racional. Os mitos e religiões passam a ser objeto de análise da razão crítica, entretanto, sem considerar as influências humanas em seu conteúdo. Lopes ${ }^{45}$, por sua vez, considera que a cristandade chega ao fim, e o jus naturalismo ocupa o seu lugar enquanto corrente jurídica que guia a humanidade. Dentre as características relevantes do jus naturalismo, pode ser elencado seu caráter individualista, reafirmando o sujeito individual e sua razão própria. Da mesma forma, atenta-se para a razão que guia seus institutos,

39 MARX, Karl; ENGELS, Friedrich. Manifesto Comunista. Edição Eletrônica, 1999. Disponível em:< http://www.ebooksbrasil.org/adobeebook/manifestocomunista.pdf> Acesso em 06 abr 2019. p.11.

40 CAMPOS, Wellington José. O Absolutismo e a formação dos Estados Nacionais. In: Histórias, Imagens e Narrativas. $\quad$ Disponível em: $<\quad$ http://egov.ufsc.br/portal/conteudo/o-absolutismo-eforma\%C3\%A7\%C3\%A3o-dos-estados-nacionais> Acesso em $20 \mathrm{Abr} .2019$.

41 De acordo com Bedin, o Estado Democrático de Direito (século XIX) caracteriza-se como um modelo de Estado subordinado ao império do Direito, com um rol de garantias fundamentais que protegem os cidadãos contra a arbitrariedade estatal, bem como tendo por base os princípios da razoabilidade e da responsabilidade. Ainda, é um Estado regulado pela limitação de seus poderes executivo, legislativo e judiciário por meio da tripartição, orienta-se pelo princípio da legalidade, liberdade e igualdade, considerando a legitimidade de seu poder pela vontade do povo. (2013, p. 150-151).

42 MORIN, Edgar. Para em:<https://www.redalyc.org/html/4955/495550182003/> Acesso em 06 abr. 2019.

43 Renascença e Iluminismo são utilizados como sinônimos. Ambos se referem ao renascimento das artes e da ciência após as "trevas" da Idade Média.

44 Para Descartes, razão trata-se da capacidade de bem-julgar, distinguindo o verdadeiro do falso, bom-senso. (2016, p. 37).

45 LOPES, 2002.

Protestantismo em Revista | São Leopoldo | v. 45, n. 02 | p. 27-44| jan./jun. 2019

Disponível em: <http:// periodicos.est.edu.br/index.php/nepp> 
podendo ser subdividida em razão instrumental, operando a relação entre meios e fins, e a razão estratégica, incidindo em relações de oportunidades de ações para alcançar os fins desejados. Gradativamente, a razão instrumental adquire protagonismo neste período. A concepção de sociedade concentra-se na questão da soma de indivíduos isolados, originando a teoria do Contrato Social ${ }^{46}$ de Rousseau. As relações sociais passam a ser tidas como contratualistas, transformando o papel do Direito e do soberano: o objetivo da autoridade estatal não é mais a justiça como era para os gregos, mas sim a paz entre os indivíduos submissos a sua ordem. A ética, da mesma forma, transforma-se da virtude para o estrito cumprimento das regras e deveres, marcando o espírito procedimentalista da modernidade. O poder, o Estado e o convívio social não são mais justificados apenas pelo objetivo de bem comum, sua legitimidade encontra-se também no cumprimento de procedimentos legalmente impostos, impelindo cada vez mais a ciência jurídica a adquirir status de razão escrita.

O Iluminismo possibilitou, além da supremacia da razão científica sobre a teológica, o processo de secularização da Igreja Católica. A secularização é reconhecida como o processo de enfraquecimento do poderio da instituição eclesiástica no ocidente. Em seus estudos, Gianni Vattimo considera que por secularização “indica-se o processo de «deriva» que liberta a civilização laica moderna das suas origens sagradas. [...] é também perda de autoridade temporal por parte da Igreja, autonomização da razão humana em relação à dependência de um Deus absoluto" 47 . Desta forma, reivindica-se a separação das esferas governamentais e religiosas, pois a razão humana não deve mais ser ditada pelos preceitos bíblico-religiosos. Assim, a Igreja passa a ocupar a seara da vida privada dos cidadãos, atuando no campo da moral, do costume e da tradição, enquanto que o Estado permanece responsável pela organização da vida pública por intermédio das leis e das instituições governamentais. Este processo não foi homogêneo em todas as nações da Europa, uma vez que cada Estado soberano poderia legislar de acordo com seus interesses em manter ou não a Religião no espaço público. ${ }^{48}$ Neste sentido, cabe lembrar que "o Estado francês foi hostil à religião, querendo banir do espaço público qualquer traço religioso, enquanto na Inglaterra houve a inclusão de todas as crenças religiosas no espaço público, desde que respeitassem a ordem pública." 49 .

Entretanto, o Estado não desconsiderou o auxílio da Igreja para legitimar sua dominação em determinados acontecimentos determinantes. Nas Grandes Navegações (século XV) protagonizadas por Portugal e Espanha, e com o processo de colonização

De acordo com Rousseau, os indivíduos reúnem-se em um acordo tácito sob a ordem jurídica de um Estado para, exclusivamente, garantir a manutenção de sua sobrevivência. Desta forma, cedem uma parte de sua autonomia e liberdade para o convívio coletivo, a fim de que, em troca, recebam do ente soberano possibilidades de sobrevivência e dignidade adequadas. Se o Estado não cumprir seu papel de garantidor de qualidade de vida aos cidadãos, perde, portanto, sua legitimidade enquanto instituição popular. (ROUSSEAU, 2002, p. 22-26).

47 VATTIMO, 1998, p. 32.

48 SCALQUETTE, 2013.

49 SCALQUETTE, 2013, p. 130.

Protestantismo em Revista | São Leopoldo | v. 45, n. 01 | p. 27-44| jan./jun. 2019

Disponível em: <http://periodicos.est.edu.br/index.php/nepp> 
europeia no recém-descoberto território americano, a dominação dos povos nativos foi possível por meio da guerra ou, principalmente, através da catequese. Padres missionários da Igreja Católica eram enviados às aldeias indígenas para, através da pregação dos ensinamentos cristãos, auxiliar no projeto estatal de aculturação dos povos nativos, a fim de utilizar suas terras e sua mão-de-obra para a exploração de matérias primas. O Direito, neste contexto, foi inserido e fiscalizado nas aldeias por intermédio dos padres, sendo uma espécie de derivação da lei de Portugal ou da Espanha. ${ }^{50}$ Desta forma, percebe-se que o Direito Europeu foi implantado na América por intermédio da Igreja. Apesar das leis não se restringirem ao crivo exclusivo do papa, como propunha Gregório VII, não se pode negar a influência religiosa que carregavam, desde alguns institutos jurídicos, como o caso do casamento monogâmico, até sua forma de ensino, através de padres missionários. Neste sentido, cabe uma análise da formação do Direito no Brasil e a influência que o Catolicismo Apostólico Romano exerceu para a consolidação das legislações no país.

Especificamente, no território hoje correspondente ao Brasil, onde o processo de colonização foi conduzido por Portugal, a formação de seu ordenamento jurídico merece especial atenção, pois segundo Cristiani ${ }^{51}$, o Direito brasileiro não surgiu a partir da evolução milenar de sua sociedade, mas se tratou da ordem imposta de um povo sobre o outro, de caráter exploratório, ignorando as particularidades geográficas, étnicas e culturais. A formação da sociedade brasileira ocorreu inicialmente pelo encontro dos povos indígenas com os europeus e a chegada dos escravos africanos para trabalho forçado na produção do açúcar, a partir do século XVI, estendendo-se até o século XIX. Porém, as legislações trazidas de Portugal desconsideravam a existência de povos originários e diferenciados, concentrando as normas em benefício dos brancos, enquanto legalizava a exploração dos demais. Ressalta-se que os primeiros diplomas normativos foram as Ordenações Afonsinas (1466), as Ordenações Manuelinas (1521) e as Ordenações Filipinas (1603). O papel da Igreja, neste período, era atuar por intermédio de seus representantes missionários para, da forma mais pacífica possível, permitir que as leis fossem aceitas pela população. Para Azevedo, neste período, “a Igreja era uma instituição subordinada ao Estado e a religião oficial funcionava como instrumento de dominação social, política e cultural."52

Já em meados do século XIX, com as Influências Iluministas europeias introduzidas no cenário brasileiro, percebe-se a movimentação do clero contra as leis impostas pela coroa portuguesa, pois acreditavam que deveriam responder unicamente ao Papado de Roma e não mais atuar como intermediário entre a dominação da metrópole sobre a colônia brasileira. Esta desvinculação do poder religioso com o poder imperial de Portugal apoiou

50 COLAÇO, Thais Luzia. O Direito nas Missões Jesuíticas da América do Sul. In: WOLKMER, Antonio Carlos [org.]. Fundamentos de História do Direito. Belo Horizonte: Del Rey, 2014, p. 265- 294.

51 CRISTIANI, Claudio Valentim. O Direito no Brasil Colonial. In: WOLKMER, Antônio Carlos. Fundamentos de História do Direito. Belo Horizonte: Delrey, 2014. p. 459-475.

52 AZEVEDO, Dermi. A Igreja Católica e seu papel político no Brasil. $2004 . \quad$ Disponível em:<http://www.scielo.br/scielo.php?script=sci_arttext\&pid=S0103-40142004000300009> Acesso em 06 abr 2019. s.p. 
de maneira consistente o movimento pela independência brasileira em 1822. ${ }^{53}$ Percebe-se forte vinculação histórica entre o poder religioso e o poder estatal brasileiro através das legislações, principalmente pela Constituição de 1824, que firmava o catolicismo como religião oficial do império. Neste sentido, o artigo $5^{\circ}$ da Carta Imperial discorria acerca da possibilidade de cultos diversos do religioso em âmbito privado e doméstico, não o admitindo em seara pública. ${ }^{54}$ Representava a segregação dos povos que compunham a sociedade da época a partir das suas crenças, legalizando a discriminação religiosa.

Apenas em 1891, após a Guerra do Paraguai (1864-1870) e a proclamação da república em 1889, o Estado brasileiro reconheceu a laicidade ${ }^{55}$ em seu ordenamento. Segundo estudiosos no assunto, esta mudança paradigmática foi resultado da crise nas finanças públicas da época, que exigiu a extinção de alguns benefícios do clero, causando tensão entre o governo e a Igreja. O princípio da laicidade foi incluso pelo Decreto $\mathrm{n}^{\mathrm{o}} 119-\mathrm{A}$ de 1890, que descaracterizava o catolicismo como religião oficial e permitia que todas as manifestações de crenças religiosas fossem externalizadas em igualdade de direitos. ${ }^{56}$ Entretanto, essa presunção não é absoluta, pois a título exemplificativo, na Constituição brasileira de 1934, houve a imposição do ensino religioso católico nas escolas públicas, bem como a exigência da presença de representantes das capelas nas forças militares e a subordinação do Estado em relação às atividades de assistência da Igreja Católica. ${ }^{57}$ Porém, em aspecto formalístico, as demais constituições brasileiras mantiveram o princípio da laicidade em seu texto, mesmo que compreendido de forma indireta. Na até então vigente Constituição da República Federativa de 1988, o princípio é vislumbrado através do artigo $5^{\circ}$, inciso VI, que dispõe:

Art. $5^{\circ}$ Todos são iguais perante a lei, sem distinção de qualquer natureza, garantindo-se aos brasileiros e aos estrangeiros residentes no País a inviolabilidade do direito à vida, à liberdade, à igualdade, à segurança e à propriedade, nos termos seguintes:

$[\ldots]$

VI - é inviolável a liberdade de consciência e de crença, sendo assegurado o livre exercício dos cultos religiosos e garantida, na forma da lei, a proteção aos locais de culto e a suas liturgias. ${ }^{58}$

Entretanto, no plano material, não é possível desvincular as influências religiosas do contexto normativo brasileiro da atualidade, principalmente em aspecto hegemônico, representando um obstáculo a ser superado para a concretização de alguns direitos. A

AZEVEDO, 2004, s.p.

SCALQUETTE, 2013.

De acordo com Bertaso e Hahn, o princípio da laicidade caracteriza-se resumidamente pelo seu ideal republicano, que promove a separação do Estado e da Igreja de forma a possibilitar o surgimento da organização pública voltada ao interesse coletivo e não mais aos dogmas religiosos. (2017, p. 583).

56 SCALQUETTE, 2013.

57 AZEVEDO, 2004.

58 BRASIL. Constituição da república federativa do brasil de 1988 . Disponível em:< http://www.planalto.gov.br/ccivil_03/Constituicao/Constituicao.htm> Acesso em 12 abr. 2019. 
Constituição Imperial de 1824, por exemplo, em seu artigo 95, inciso III, proibia que o cidadão que não professasse a Religião oficial do Estado apresentasse candidatura para o cargo de deputado. Da mesma forma, em seu artigo 179, inciso V, proibia a perseguição religiosa, exceto em situação de desrespeito ao catolicismo e à moral pública. ${ }^{59}$ Apesar de parecer um dispositivo protetivo, ao não regular as condutas que seriam tidas como ofensivas à moral pública ou à Religião oficial, permitia que houvesse perseguições a praticamente qualquer tipo de manifestação contrária ao estipulado legalmente.

Atualmente, as legislações brasileiras estão mais receptivas aos ideais contra hegemônicos, no sentido de se encontrarem mais garantias individuais e coletivas que amparam as minorias marginalizadas. Entretanto, as tendências teológicas conservadoras apresentam sério obstáculo para a concretização destas garantias. De acordo com Boaventura de Sousa Santos, estas teologias "rejeitam a distinção entre a esfera pública e a privada e atribuem a uma determinada religião o monopólio da organização da vida social e política" 60 . Estas correntes religiosas, ao invés de atuarem em consonância com os direitos libertários da modernidade, justificam a exploração, a desigualdade social, o colonialismo e o patriarcado com base nos preceitos divinos. Desta forma, veiculam através de manifestações e propagandas um discurso que afeta de forma negativa a credibilidade de vários movimentos sociais que reivindicam principalmente a igualdade social, religiosa e étnica, a superação do patriarcado, os direitos sexuais, reprodutivos e de liberdade de orientação sexual, sob o argumento de que "a sociedade moderna liberalizou a família, a educação e o aborto, o que é considerado uma traição dos valores cristãos." 61

A atual ciência jurídica é reconhecida pela sua autonomia em relação à Religião. Entretanto, enquanto produto humano, o Direito é responsável por positivar regras em prol do interesse social, de forma a representar a realidade vivida. Neste sentido, a Igreja Católica, ao interferir na esfera privada das relações, dissemina discursos hegemônicos que são internalizados na cultura social e, por fim, legalizados pelo Direito. Neste sentido, apesar da emergência do racionalismo na modernidade possibilitar o surgimento de algumas legislações em prol dos direitos das minorias, pela promoção do afastamento das teorizações em face do mito religioso, não foi suficientemente eficaz no combate aos ideais hegemônicos internalizados na cultura ocidental. Percebe-se que a Igreja perdeu muito de seu poder de influência direta sobre as decisões estatais, ficando submissa ao império do monarca e, posteriormente, do Direito positivo instituído pela razão humana. Entretanto, para Morin, não se pode conceber uma legítima superação da arbitrariedade divina nas tendências racionalistas, pois, “a Razão soberana converte-se ela mesma em razão providencial e em mito quase religioso, alcançando até mesmo um momento transitório de verdadeira deificação com a instituição por Robespierre do culto à "Deusa" Razão."62. http://www.planalto.gov.br/ccivil_03/Constituicao/Constituicao24.htm> Acesso em 12 abr. 2019.

60 SANTOS, 2014, p. 36.

61 SANTOS, 2014, p. 70.

62 MORIN, 2005, p. 24. 
Nestas palavras de Edgar Morin, constata-se um perigo: a razão adquiriu o mesmo status da ordem divinizada. Há, portanto, o desafio de uma constante vigilância para que a razão não seja sacralizada e endeusada.

\section{Considerações finais}

De acordo com as pesquisas de Boaventura de Sousa Santos, percebe-se que o movimento racionalista agiu em não-hegemonia63, pois destituiu da Igreja o poder de ditar a verdade e reivindicou-o para si mesmo. Consoante, Vattimo complementa que a razão e a técnica, da mesma forma que a Religião fizera na Idade Média, trouxeram sérios prejuízos à humanidade no sentido de atuar de forma desmedida e arbitrária. Exemplificativamente, tem-se as questões atualmente ligadas à bioética, manipulação genética, desastres ecológicos e novas formas de dominação pautadas pela desigualdade, marginalização, violência e pobreza como resultantes do processo de produção desequilibrado de riquezas entre os países. ${ }^{64}$ Isto significa pensar que, mesmo após a secularização da Igreja Católica no ocidente, a estrutura linguística metafísica persistiu na base das organizações estatais, legislativas e sociais, de forma a legitimar a hegemonia sob o fundamento racionalista. Portanto, a fim de permitir que direitos e garantias sejam proporcionados de forma igual a toda e qualquer pessoa, atuando como instrumento contra hegemônico, é necessário o combate da estrutura linguística metafísica que legitimava a dominação e a desigualdade.

Como conclusão, enfatiza-se que o Direito e a Religião são essencialmente estruturas de linguagem e a estrutura de linguagem metafísica, oriunda da Filosofia grega, foi determinante para a influência da religião cristã sobre a formação da realidade jurídica ocidental. Uma das razões, sem dúvida, de muitas injustiças e violências, foi a estrutura linguística metafísica presente tanto no discurso jurídico, como no discurso religioso. Vigiar e desconstruir este discurso evidencia-se eticamente imperativo para ver realidades e ouvir vozes de minorias, de estrangeiros, de quem encontra-se à margem. Eis um dos desafios para a ciência jurídica e para a ciência teológica.

\section{Referências}

ANDERSON, Perry. El estado absolutista. Madrid: Siglo XXI, 2007.

ARISTÓTELES. Ética a Nicômaco. São Paulo: Nova Cultural. Edição digital, 1991. Disponível em:< https://abdet.com.br/site/wp-content/uploads/2014/12/\%C3\%89tica-aNic\%C3\%B4maco.pdf> Acesso em 06 abr 2019.

63 Nas palavras de SANTOS: “Considero não hegemônicas as atuações sociais (lutas, iniciativas e práticas) que resistem contra formas hegemônicas de dominação que reproduzem ou mesmo agravam as desigualdades das relações de poder social." (2014, p. 35).

64 VATTIMO, 1998. 
AZEVEDO, Dermi. A Igreja Católica e seu papel político no Brasil. 2004. Disponível em:<http:/ / www.scielo.br/scielo.php?script=sci_arttext\&pid=S0103-40142004000300009> Acesso em 06 Abr. 2019.

BBCBRASIL. Estudo do Vaticano diz que Inquisição torturou e matou menos do que se pensava. 2004.

Disponível em:<https://www.bbc.com/portuguese/noticias/story/2004/06/040616_vaticanoms.sht $\underline{\mathrm{ml}>\text { Acesso em } 06 \text { Abr. } 2019 .}$

BEDIN, Gilmar Antônio. Estado de Direito: tema complexo, dimensões essenciais e conceito. In: Direito em Debate. Ijuí: Unijuí, 2013. Ano XXII, nº 39. P. 144-152.

BEDIN, Gilmar Antônio. Os direitos do homem e o neoliberalismo. Ijuí: Ed. Unijuí, 2002.

BERTASO, João Martins; HAHN, Noli Bernardo. O princípio da laicidade, direitos humanos e profecia hebraica: conexões possíveis. In: Novos Estudos Jurídicos. Univali: 2017. P. 575-594. Disponível em:< https://siaiap32.univali.br/seer/index.php/nej/article/view/10987> Acesso em 12 Abr. 2019.

BRASIL. Constituição da república federativa do Brasil de 1988. Disponível em:< http://www.planalto.gov.br/ccivil_03/Constituicao/Constituicao.htm> Acesso em 12 abr 2019.

BRASIL. Constituição politica do imperio do Brazil (de 25 de março de 1824). Disponível em:< http://www.planalto.gov.br/ccivil_03/Constituicao/Constituicao24.htm> Acesso em 12 abr 2019.

CAMPOS, Wellington José. O Absolutismo e a formação dos Estados Nacionais. In: Histórias, Imagens e Narrativas. Disponível em:< http://egov.ufsc.br/portal/conteudo/oabsolutismo-e-forma \%C3\% A7\%C3\% A3o-dos-estados-nacionais> Acesso em 20 abr 2019

COLAÇO, Thais Luzia. O Direito nas Missões Jesuíticas da América do Sul. In: WOLKMER, Antonio Carlos. Fundamentos de História do Direito. Belo Horizonte: Delrey, 2014. p. 425-458.

CRISTIANI, Claudio Valentim. O Direito no Brasil Colonial. In: WOLKMER, Antonio Carlos. Fundamentos de História do Direito. Belo Horizonte: Delrey, 2014, p. 459-475.

DESCARTES, René. Discurso do Método. Porto Alegre: L\&PM POCKET, 2016.

GIRARDI, Leopoldo Justino. Noções Elementares de História do Direito. 2. ed., Santa Rosa: COLI Gráfica e Editora LTDA, 2009.

HOMMERDING, Adalberto Narciso. As doutrinas jurídicas cristãs da Idade Média: do voluntarismo agostiniano ao nominalismo de Guilherme de Ockham. De Ockham a teoria jurídica contemporânea. In: ROCHA, Leonel Severo; OLIVEIRA JUNIOR, José Alcebíades de. Diálogo e Entendimento: direito e multiculturalismo e políticas de cidadania e resolução de conflitos. CAPINAS: Millenium, 2018. Tomo 9. Pgs 191-216.

KNOWLES, David; OBOLENSKY, Dimitri. Nova História da Igreja II: A Idade Média. Petrópolis: Vozes Ltda, 1973.

LEVINAS, Emmanuel. Totalidade e Infinito. Lisboa: Edições 70, 1980.

LOPES, José Reinaldo de Lima. O Direito na História: lições introdutórias. São Paulo: Max Limonad, 2002.

MARX, Karl. O Capital: crítica da economia política. São Paulo: Boitempo. Edição eletrônica, 2017.

Disponível

em: $<$ 
https://coletivocontracorrente.files.wordpress.com/2013/10/tmpsq7jbv.pdf> Acesso em 06 abr 2019.

MARX, Karl; ENGELS, Friedrich. Manifesto Comunista. Edição Eletrônica, 1999. Disponível em:< http://www.ebooksbrasil.org/adobeebook/manifestocomunista.pdf> Acesso em 06 abr 2019.

MORIN, Edgar. Para além do Iluminismo. 2005. Disponível em:<https:/ / www.redalyc.org/html/4955/495550182003/> Acesso em 06 abr 2019.

NASPOLINI, Samyra Haydeê. Aspectos Históricos, Políticos e legais da Inquisição. In: WOLKMER, Antonio Carlos [org.]. Fundamentos de História do Direito. Belo Horizonte: Del Rey, 2014, p. 282- 298.

NIETZSCHE, Friedrich. O Anticristo. Tradução de Renato Zwick. Porto Alegre: L \& PM, 2008.

ROSSEAU, Jean-Jacques. Do Contrato Social. Edição Eletrônica. Disponível em: < http://www.ebooksbrasil.org/adobeebook/contratosocial.pdf> Acesso em 6 abr 2019.

SANTOS, Boaventura de Sousa. Se Deus fosse um ativista dos direitos humanos. São Paulo: Cortez, 2014.

SANTOS, Rogério Dultra dos. A Institucionalização da Dogmática Jurídico-Canônica Medieval. In: WOLKMER, Antonio Carlos [org.]. Fundamentos de História do Direito. Belo Horizonte: Del Rey, 2014.

SCALQUETTE, Rodrigo Arnoni. História do Direito: perspectivas histórico-constitucionais da relação entre Estado e Religião. São Paulo: Atlas, 2013.

VATTIMO, Gianni. Acreditar em Acreditar. Lisboa: Relógio D'Água Editores, 1998.

. Adeus à Verdade. Petrópolis: Vozes, 2016.

; DE CAPUTO, John. Después de la muerte de Dios: conversaciones sobre

religión, política y cultura. Barcelona: Paidós, 2010. 